\title{
Precipitate coarsening parameters for gas induced semi-solid cast 7075-T6 Al alloy determined by SAXS measurements
}

\author{
N MAHATHANINWONG ${ }^{1, *}$, S WISUTMETHANGOON ${ }^{2}$, T CHUCHEEP ${ }^{1}$, S JANUDOM $^{3}$ and \\ R CANYOOK ${ }^{4}$ \\ ${ }^{1}$ Faculty of Science and Industrial Technology, Prince of Songkla University, Surat Thani Campus, Muang, Surat Thani \\ 84000, Thailand \\ ${ }^{2}$ Department of Mechanical Engineering, Faculty of Engineering, Prince of Songkla University, Hat Yai, Songkhla 90112, \\ Thailand \\ ${ }^{3}$ Department of Mining and Materials Engineering, Faculty of Engineering, Prince of Songkla University, Hat Yai, \\ Songkhla 90112, Thailand \\ ${ }^{4}$ Department of Materials and Production of Technology Engineering, Faculty of Engineering, King Mongkut's University \\ of Technology North Bangkok, Bangkok 10800, Thailand \\ *Author for correspondence (narissara.s@psu.ac.th)
}

MS received 3 August 2016; accepted 27 March 2017; published online 31 October 2017

\begin{abstract}
The particle radii of precipitates in the gas induced semi-solid (GISS) cast 7075-T6 Al alloys, for ageing times ranging from peak ageing to over ageing, were measured by small-angle X-ray scattering (SAXS) technique. The measured precipitate radii increased with ageing time and temperature, and data were well fit by the Lifshitz-Slyozov-Wagner (LSW) coarsening process along with a modified Arrhenius equation for temperature dependency. The activation energy for the coarsening process was estimated at $1.19 \mathrm{eV}$, which is close to that of the wrought $7075 \mathrm{Al}$ alloy. This energy is in the range of activation energies of $\mathrm{Zn}, \mathrm{Mg}$ and $\mathrm{Cu}$ for their diffusion in $\mathrm{Al}$. The precipitate coarsening rate of this alloy appears to be diffusion limited. The fine precipitates of the GISS 7075-PA Al alloy coarsened slowly at $63 \mathrm{~nm}^{3} \mathrm{~h}^{-1}$ rate, at the elevated $200^{\circ} \mathrm{C}$ temperature, while rapid $216 \mathrm{~nm}^{3} \mathrm{~h}^{-1}$ coarsening was found in the wrought 7075 -T651 Al alloy.
\end{abstract}

Keywords. $7075 \mathrm{Al}$ alloy; gas induced semi-solid; small angle X-ray scattering; precipitate coarsening.

\section{Introduction}

Mechanical properties of the wrought $7075 \mathrm{Al}$ alloy are superior to those of other $\mathrm{Al}$ alloys. This is a precipitate hardening alloy [1]. Precipitates of the alloy after ageing have been analysed to gain understanding of the precipitate hardening mechanisms. Such information on various wrought $7 \mathrm{xxx} \mathrm{Al}$ alloys is available especially on the wrought $7075 \mathrm{Al}$ alloy $[2,3]$. Previous work [4] was reported on the peak aged condition of the cast $7075 \mathrm{Al}$ alloy, which was produced by semi-solid forming process through gas induced semi-solid (GISS) technique. Precipitates at peak aged and onset hardness plateau times of the alloy were also characterized by transmission electron microscope (TEM). The tensile strength of GISS 7075-T6 was found to be comparable to that of some thixo-formed products but lower than that of wrought 7075T651. However, surprisingly its creep resistance was superior to wrought 7075-T651 [5]. Hence, it is of interest to study the behaviour of precipitate coarsening in the GISS processed 7075-T6 Al alloy in order to figure out the potential for using this alloy at elevated temperatures and surpassing the properties of the wrought $7075 \mathrm{Al}$ alloy.
This work will further investigate the precipitate evolution of the alloy aged at $120,145,165$ and $185^{\circ} \mathrm{C}$ for various times after peak ageing and onset of hardness plateau times. The influence of ageing temperature and time on the precipitate evolution of the alloy was investigated, mainly by small angle $\mathrm{X}$-ray scattering (SAXS), to gain a better understanding of the precipitate coarsening mechanisms in the alloy. Furthermore, the precipitate coarsening was determined as well, for both the GISS 7075-T6 PA and the wrought 7075-T651 Al alloy, at the elevated $200^{\circ} \mathrm{C}$ temperature.

\section{Experimental}

The semi-solid cast $7075 \mathrm{Al}$ alloy was prepared through the GISS process, as detailed in the previous work [4]. The wrought $7075 \mathrm{Al}$ alloy used in the present work was received as 12.7-mm-thick rolled plates in the T651 condition, to be used in comparisons. The chemical compositions of the alloys are shown in table 1 and were determined by optical emission spectroscopy.

The as-cast plates were cut into small $15 \times 50 \times 15 \mathrm{~mm}$ samples and subjected to T6 heat treatment. These samples 
Table 1. Chemical composition of the GISS cast 7075-T6 Al alloy (GISS) and the wrought $7075 \mathrm{Al}$ alloy (wrought) in wt $\%$.

\begin{tabular}{lcccccccc}
\hline Element & $\mathrm{Zn}$ & $\mathrm{Mg}$ & $\mathrm{Cu}$ & $\mathrm{Fe}$ & $\mathrm{Si}$ & $\mathrm{Cr}$ & $\mathrm{Mn}$ & $\mathrm{Al}$ \\
\hline GISS & 6.08 & 2.50 & 1.93 & 0.46 & 0.40 & 0.19 & 0.03 & Bal. \\
Wrought & 5.92 & 2.64 & 1.70 & 0.19 & 0.07 & 0.19 & 0.04 & Bal. \\
\hline
\end{tabular}

were solution heat treated at $450^{\circ} \mathrm{C}$ for $4 \mathrm{~h}$, quenched in $25^{\circ} \mathrm{C}$ water, after that artificially aged at $120,145,165$ and $185^{\circ} \mathrm{C}$ beyond the peak ageing time and the onset of the hardness plateau [4]. The GISS 7075-T6 Al alloy aged after peak age at $120^{\circ} \mathrm{C}$ for $72 \mathrm{~h}$ (GISS-PA), and the as-received wrought (AR-W) $7075-\mathrm{T} 651 \mathrm{Al}$ alloy was heated at $200^{\circ} \mathrm{C}$ for $1 \mathrm{~h}$ or for $4 \mathrm{~h}$.

To prepare TEM specimens, each specimen was machined into a 3-mm diameter rod inserted in wood. This rod was then sliced into approximately $0.8 \mathrm{~mm}$ thick discs using a low speed diamond saw. Both sides of the discs were mechanically polished with 1200 -grit $\mathrm{SiC}$ and $5 \mu \mathrm{m}$ micro-polishing alumina powder, leaving a 40-60 $\mu \mathrm{m}$ thick sample. These thin disc specimens were then electropolished in a Tenupol- 3 electropolisher, with a solution of $20-25 \mathrm{vol} \%$ nitric acid and $80-75$ vol $\%$ methanol at -15 to $-20^{\circ} \mathrm{C}$ and an applied current of 1.2-1.5 A. Each electropolished specimen was immersed into methanol for cleaning. The electropolished specimens were then characterized using a JEM-2010 JEOL TEM at MTEC.

The SAXS specimens were thin sheets cut from these aged samples with a $7 \mathrm{~mm} \times 7 \mathrm{~mm}$ face and a 50-70 $\mu \mathrm{m}$ thickness. The proven quantitative analysis of precipitates in $\mathrm{Al}$ alloys by SAXS technique dates back to more than 30 years [6]. This study used the SAXS beamline of the Siam Photon Laboratory in the Synchrotron Light Research Institute (SLRI), Suranaree University of Technology, Thailand, which was opened for users in March 2011, as described in [7,8]. The incident $\mathrm{X}$-rays had $8-9.5 \mathrm{keV}$ energy and their scattering vector $\mathrm{q}$ was in the range from 0.1 to $2.5 \mathrm{~nm}^{-1}$, and the sample to detector distance was 1.2 and $4.5 \mathrm{~m}$.

\section{Results and discussion}

\subsection{TEM micrographs}

Figure $1 \mathrm{a}$ and $\mathrm{b}$ shows representative images of precipitate for the GISS $7075 \mathrm{Al}$ alloy aged at $120^{\circ} \mathrm{C}$ for $72 \mathrm{~h}$ (peak ageing) and for $132 \mathrm{~h}$ (over ageing), respectively. The precipitates at their peak aged condition were finer and could not be quantified as mentioned in a previous study by Mahathaninwong et al [4]. The coarsening of precipitates was obvious when ageing time was extended to $132 \mathrm{~h}$. Figure $1 \mathrm{c}$ shows the precipitate morphology of the specimen aged at $145^{\circ} \mathrm{C}$ for $6 \mathrm{~h}$ with the average diameter being $4.09 \mathrm{~nm}$ [4]. The precipitates
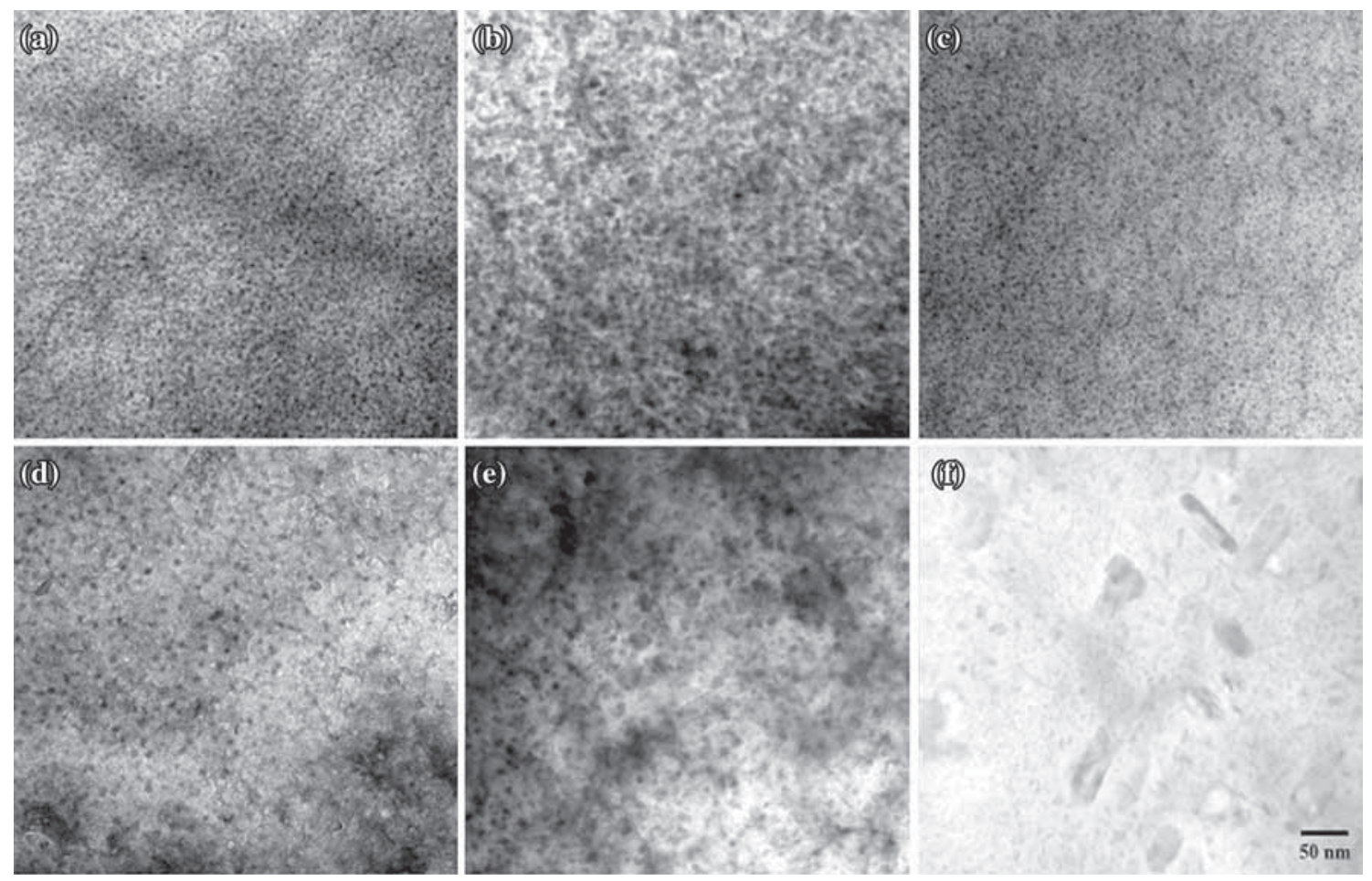

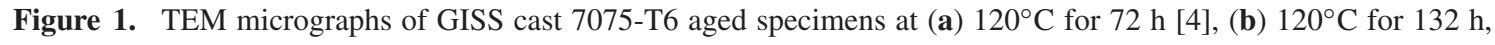
(c) $145^{\circ} \mathrm{C}$ for $6 \mathrm{~h},(\mathbf{d}) 145^{\circ} \mathrm{C}$ for $24 \mathrm{~h}$, (e) $145^{\circ} \mathrm{C}$ for $72 \mathrm{~h}$ and of (f) as-received wrought $7075-\mathrm{T} 651 \mathrm{Al}$ alloy. 
became coarser with 24 and $72 \mathrm{~h}$ ageing times as shown in figure $1 \mathrm{~d}$ and e, respectively. TEM images of specimens aged at $165^{\circ} \mathrm{C}$ for $3 \mathrm{~h}$ and at $185^{\circ} \mathrm{C}$ for $1 \mathrm{~h}$ have been shown in previous work [4].

It was reported in a previous study [5] that the creep resistance of GISS cast 7075-T6 $\mathrm{Al}$ alloy aged at $120^{\circ} \mathrm{C}$ for $72 \mathrm{~h}$ was superior to that of the wrought $7075 \mathrm{Al}$ alloy, when observed at $200^{\circ} \mathrm{C}$ for stresses in the range $120-180 \mathrm{MPa}$. The precipitates of the wrought alloy before creep test are shown in figure 1f. Dense and fine precipitates prevailed in the microstructure of the GISS alloy as seen in figure 1a. Moreover, the precipitate size in the alloy is rather uniform. In contrast, large sized precipitates appeared alongside the fine precipitates in the microstructure of the wrought $\mathrm{Al}$ alloy. No quantitative analysis of these precipitates has been reported in prior studies. The quantitative characterization of both these alloys is investigated here with SAXS.

\subsection{Small angle X-ray scattering}

A SAXS data processing programme, SAXSIT (small angle $\mathrm{X}$-ray scattering image tool) [9], was used to determine the Guinier (Gyration) radius $\left(R_{\mathrm{G}}\right)$. Following the Guinier approximation, the scattered intensity can be written as given in equation (1) [6];

$$
I(q)=I_{\mathrm{e}} N n^{2} e^{-R_{\mathrm{G}}^{2} q^{2} / 3}
$$

Where $I(q)$ is the relative scattered intensity, $I_{\mathrm{e}}$ is the scattered intensity by one electron, $n$ is the total electron count in one particle and $N$ the total number of particles in the field irradiated by X-rays. $R_{\mathrm{G}}$ is calculated through the slope $m$ in a Guinier plot of $\ln I$ and $q^{2}$, with $R_{\mathrm{G}}=\sqrt{(-3 m)}$. An average radius $(R)$ of spherical and ellipsoidal precipitate particles can be estimated as shown below in equation (2);

$$
R=\sqrt{\frac{5}{3}} R_{\mathrm{G}} .
$$

The scattering curves for the GISS-cast 7075-T6 specimens, aged in the range of $120-185^{\circ} \mathrm{C}$ temperatures for various times, are shown in figures 2 and 3 as semi-log plots of $\log$ I vs. $q^{2}$. The scattering curves for GISS-cast 7075-T6 aged at $120^{\circ} \mathrm{C}$ for $1 \mathrm{~h}$ (GISS-PA) and wrought $7075-\mathrm{T} 651$, heated at $200^{\circ} \mathrm{C}$ for 1 and $4 \mathrm{~h}$, are shown in figures 4 and 5 . The observations appear nearly linear over the small angle region. Therefore, the Guinier radii were calculated from the slopes observed in the range $0.8<q * R<2$ [10], and the average $R_{\mathrm{G}}$ and $R$ are summarized in table 2 .

The average precipitate radius of peak aged specimen was consistent with that of $7150 \mathrm{Al}$ alloy aged at $120^{\circ} \mathrm{C}$ for $24 \mathrm{~h}$ [11], while a finer $2.13 \mathrm{~nm}$ precipitate radius has been reported for the wrought $7075 \mathrm{Al}$ alloy aged at $120^{\circ} \mathrm{C}$ for $72 \mathrm{~h}$ [2]. At each ageing temperature the average precipitate radius increased significantly with observed ageing times up to $72 \mathrm{~h}$

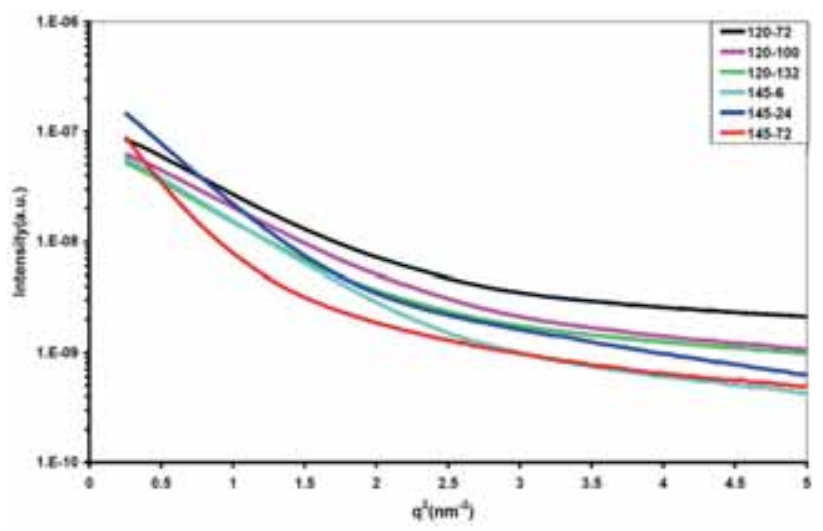

Figure 2. Guinier semi-log plots of $I$ vs. $q^{2}$ for the 7075-T6 Al alloy aged at $120^{\circ} \mathrm{C}$ for $72 \mathrm{~h}(120-72), 100 \mathrm{~h}(120-100)$ and $132 \mathrm{~h}$ (120-132); and at $145^{\circ} \mathrm{C}$ for $6 \mathrm{~h}$ (145-6), $24 \mathrm{~h}(145-24)$ and $72 \mathrm{~h}$ (145-72).

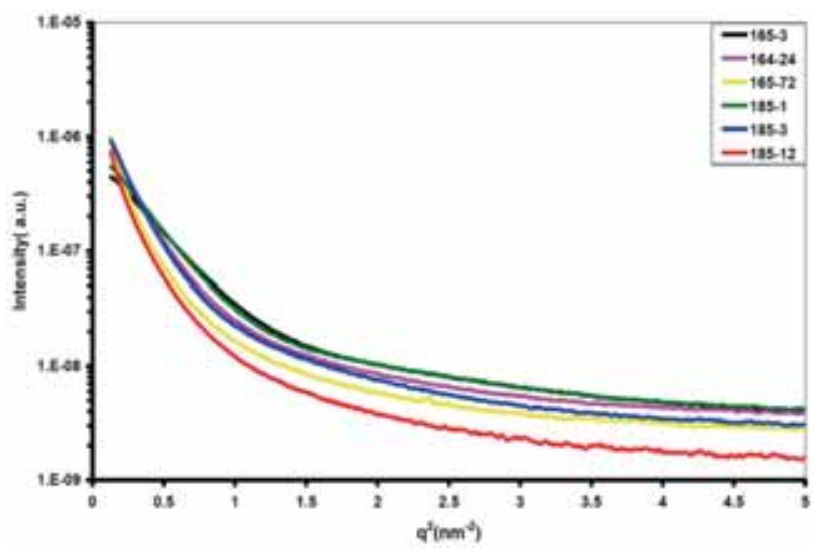

Figure 3. Guinier semi-log plots of $I$ vs. $q^{2}$ for the 7075-T6 Al alloy aged at $165^{\circ} \mathrm{C}$ for $3 \mathrm{~h}(165-3), 24 \mathrm{~h}(165-24)$ and $72 \mathrm{~h}(165-$ 72); and at $185^{\circ} \mathrm{C}$ for $1 \mathrm{~h}(185-1), 3 \mathrm{~h} \mathrm{(185-3)}$ and $12 \mathrm{~h}(185-12)$.

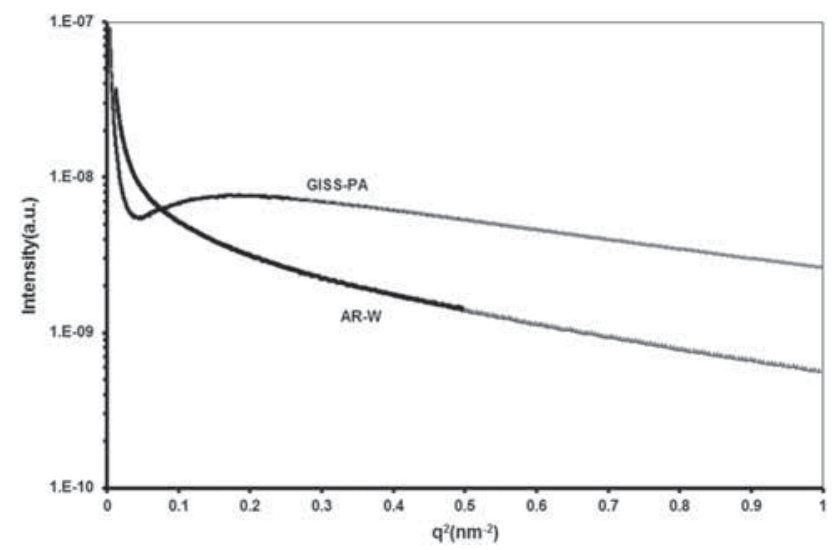

Figure 4. Guinier semi-log plots of $I$ vs. $q^{2}$ for the 7075-T6 Al alloy aged at $120^{\circ} \mathrm{C}$ for $72 \mathrm{~h}$ (GISS-PA) and for as-received wrought 7075-T651 Al alloy (AR-W). 


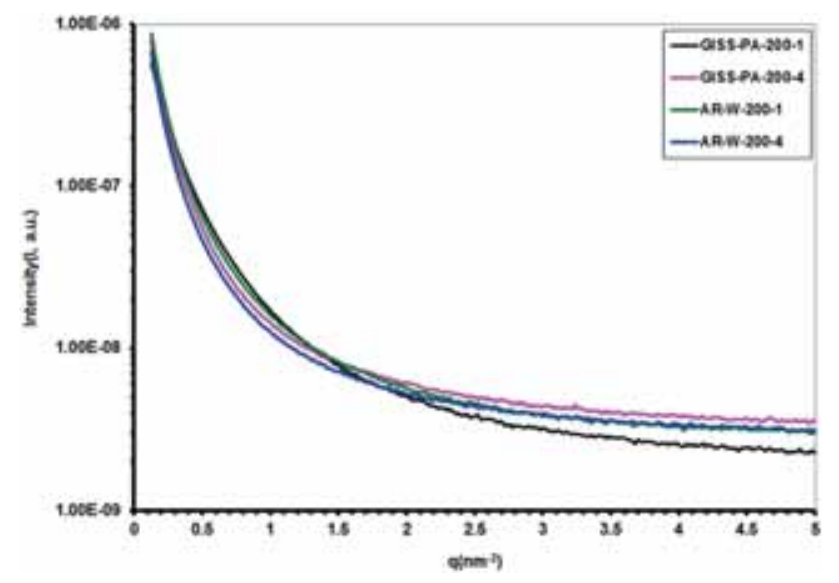

Figure 5. Guinier semi-log plots of $I$ vs. $q^{2}$ for the 7075-T6 PA heating at $200^{\circ} \mathrm{C}$ for $1 \mathrm{~h}$ (GISS-PA-200-1) and $4 \mathrm{~h}$ (GISS-PA-200-1) and as-received wrought $7075 \mathrm{Al}$ alloy heating at $200^{\circ} \mathrm{C}$ for $1 \mathrm{~h}$ (ARW-200-1) and $4 \mathrm{~h}$ (AR-W-200-4).

Table 2. The average Guinier radii and estimated precipitate radii of the GISS cast 7075-T6 and wrought 7075-T651 Al alloy for various conditions as determined from the SAXS curves.

\begin{tabular}{lcc} 
Ageing treatments & $R_{\mathrm{G}}(\mathrm{nm})$ & $R(\mathrm{~nm})$ \\
\hline $120^{\circ} \mathrm{C} / 72 \mathrm{~h}(120-72)$ & $2.09 \pm 0.16$ & $2.50 \pm 0.21$ \\
$120^{\circ} \mathrm{C} / 100 \mathrm{~h}(120-100)$ & $2.12 \pm 0.18$ & $2.52 \pm 0.23$ \\
$120^{\circ} \mathrm{C} / 132 \mathrm{~h}(120-132)$ & $2.22 \pm 0.19$ & $2.69 \pm 0.25$ \\
$145^{\circ} \mathrm{C} / 6 \mathrm{~h}(145-6)$ & $2.29 \pm 0.18$ & $2.80 \pm 0.24$ \\
$145^{\circ} \mathrm{C} / 24 \mathrm{~h}(145-24)$ & $2.68 \pm 0.05$ & $3.46 \pm 0.06$ \\
$145^{\circ} \mathrm{C} / 72 \mathrm{~h}(145-72)$ & $3.28 \pm 0.07$ & $4.31 \pm 0.09$ \\
$165^{\circ} \mathrm{C} / 3 \mathrm{~h}(165-3)$ & $2.98 \pm 0.04$ & $3.91 \pm 0.06$ \\
$165^{\circ} \mathrm{C} / 24 \mathrm{~h}(165-24)$ & $3.62 \pm 0.16$ & $4.91 \pm 0.2$ \\
$165^{\circ} \mathrm{C} / 72 \mathrm{~h}(165-72)$ & $4.07 \pm 0.38$ & $5.66 \pm 0.49$ \\
$185^{\circ} \mathrm{C} / 1 \mathrm{~h}(185-1)$ & $3.22 \pm 0.02$ & $4.17 \pm 0.02$ \\
$185^{\circ} \mathrm{C} / 3 \mathrm{~h}(185-3)$ & $3.85 \pm 0.17$ & $5.20 \pm 0.21$ \\
$185^{\circ} \mathrm{C} / 12 \mathrm{~h}(185-12)$ & $4.03 \pm 0.56$ & $5.85 \pm 0.76$ \\
$\mathrm{GISS}-\mathrm{PA}-200-1$ & $3.35 \pm 0.47$ & $4.32 \pm 0.61$ \\
$\mathrm{GISS}-\mathrm{PA}-200-4$ & $5.00 \pm 0.92$ & $6.46 \pm 1.19$ \\
$\mathrm{AR}-\mathrm{W}$ & $3.1 \pm 0.31$ & $4.00 \pm 0.40$ \\
$\mathrm{AR}-\mathrm{W}-200-1$ & $4.96 \pm 0.84$ & $6.41 \pm 1.09$ \\
$\mathrm{AR}-\mathrm{W}-200-4$ & $7.55 \pm 2.10$ & $9.75 \pm 2.72$ \\
\hline
\end{tabular}

and similarly the radii consistently increased with the ageing temperature. The obtained average precipitate radii from SAXS measurements are known to be closely similar to those determined from TEM images [4].

However, the scattering intensity of GISS-cast 7075-T6 aged at $120^{\circ} \mathrm{C}$ for $72 \mathrm{~h}$ (GISS-PA) in figure 4 was lower than that of the AR-W 7075-T651 Al alloy at lower scattering vectors. Deschamps et al [10] and Liu et al [11] propose that the scattered intensity is higher due to the larger mean radius of precipitates. The average precipitate radii of $4.00 \mathrm{~nm}$ for the wrought as-received 7075-T651 $\mathrm{Al}$ alloy is larger than that of the GISS cast 7075-T6 $\mathrm{Al}$ alloy aged at $120^{\circ} \mathrm{C}$ for $72 \mathrm{~h}$ (GISS-PA).

Figure 5 shows the scattering curves for the GISS-cast 7075 -T6 aged at $120^{\circ} \mathrm{C}$ for $72 \mathrm{~h}$ (GISS-PA) and wrought 7075-T651 Al alloy, held at $200^{\circ} \mathrm{C}$ for 1 and $4 \mathrm{~h}$. The average precipitate radius in the wrought alloy clearly increased to $6.41 \mathrm{~nm}$ when held for $1 \mathrm{~h}$ at $200^{\circ} \mathrm{C}$ and increased further to $9.75 \mathrm{~nm}$ when held for $4 \mathrm{~h}$. In the case of GISS-PA alloy, the precipitate size also increased from 2.50 to $4.32 \mathrm{~nm}$ when held at $200^{\circ} \mathrm{C}$ for $1 \mathrm{~h}$. With the holding time further increased to $4 \mathrm{~h}$, the precipitate size grew to $6.46 \mathrm{~nm}$. These results demonstrate that the precipitates in the microstructure of the wrought alloy are coarser than those in the GISS-PA alloy, at $200^{\circ} \mathrm{C}$ and that the wrought alloy experiences softening at elevated temperatures [2].

\subsection{Precipitate coarsening}

An increasing average precipitate radius with ageing time is termed a coarsening process. Our measurements of the average precipitate radii show coarsening of the precipitates with ageing that increased with temperature, consistent with the investigation of $\mathrm{Du}$ et al [2]. The coarsening of $\mathrm{Al}-\mathrm{Zn}-\mathrm{Mg}-(\mathrm{Cu})$ alloys has been well fit with the LifshitzSlyozov-Wangner (LSW) model [2,3,10-12]. This model has a linear relationship between particle volume and ageing time $(t)$, so that the precipitate radius $(R)$ evolves as given below in equation (3)

$$
R^{3}-R_{0}^{3}=K t
$$

where $K$ is the growth co-efficient. Figure 6 shows plots of $R^{3} v s$. ageing time at $120,145,165$ and $185^{\circ} \mathrm{C}$, displaying nearly linear relationships of $R^{3}$ to ageing time. The linearity corroborates the LSW model for our observed coarsening process. The growth coefficients determined from the slopes approximately follow a modified Arrhenius type temperature dependency as shown in figure 7. By extrapolation, the

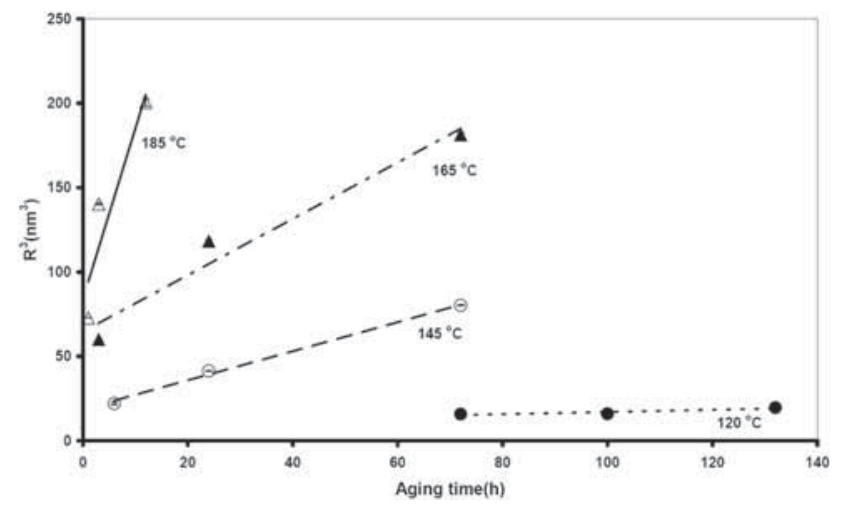

Figure 6. Plots of $R^{3} v s$. ageing time for $120,145,165$ and $185^{\circ} \mathrm{C}$ show reasonably good fit of linear volume growth models to our data. 


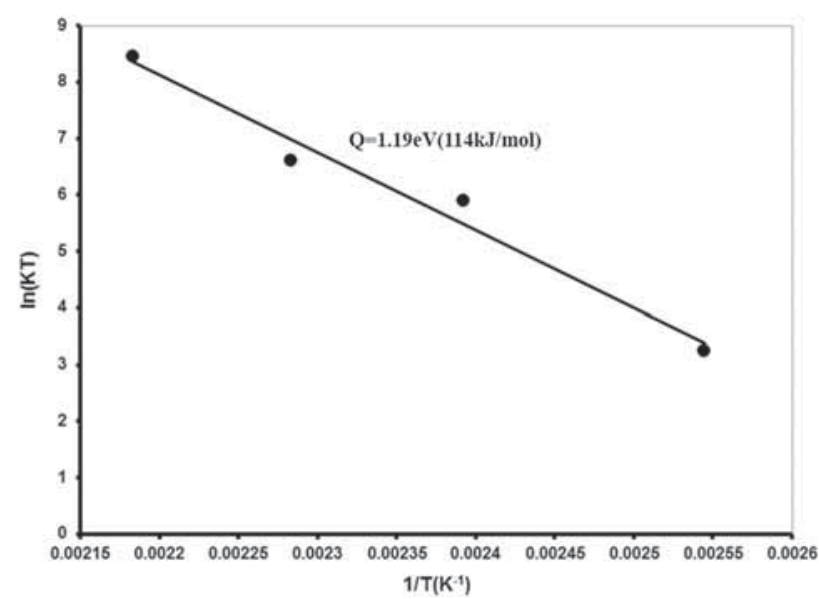

Figure 7. A plot $\ln (K T) v s$. ageing $1 / T$ is nearly linear displaying a modified Arrhenius type temperature dependency for the coarsening rates.

coarsening rate of precipitates in GISS 7075-T6 Al alloy is expected to increase with the ageing temperature also beyond our experimental range and the rates could be predicted from the approximations fit to our data.

The modified Arrhenius equation for the growth coefficient $K$ in explicit form is

$$
K=\frac{c}{T} \exp \left(\frac{Q}{k_{\mathrm{B}} T}\right),
$$

where $T$ is the ageing temperature and $c$ is a constant that depends on the precipitate-matrix interfacial energy, the average atomic volume, the equilibrium solute concentration and the solute diffusion coefficient [13]. The theoretical derivation assumes that the changes in concentration and interfacial energy are negligible.

The activation energy $Q$ in equation (4), for the precipitate coarsening of GISS 7075-T6 Al alloy, was estimated from our data as only $1.19 \mathrm{eV}\left(114 \mathrm{~kJ} \mathrm{~mol}^{-1}\right)$, which is close to the $1.22 \mathrm{eV}$ of wrought $7075 \mathrm{Al}$ alloy [2]. This activation energy is within the range $1.17-1.47 \mathrm{eV}$ of activation energies for the diffusion of $\mathrm{Cu}, \mathrm{Mg}$ and $\mathrm{Zn}$ in $\mathrm{Al}[3,14]$. The existence of an $\eta^{\prime}$ phase in the specimens aged at $120^{\circ} \mathrm{C}$ for the peak ageing time and at 145,165 and $185^{\circ} \mathrm{C}$ for the onset of hardness plateau time has been known [4]. The current study confirmed that the $\eta^{\prime}$ phase coarsens and transforms to the $\eta$ stable phase by diffusion at long ageing times. The result also suggested that the coarsening mechanism of $\eta^{\prime}$ phase is controlled by volume diffusion and there is no interaction among the $\eta^{\prime}$ phase particles corresponding to the LSW theory.

In addition, the coarsening dynamics of the GISS 7075-T6 Al alloy appear rather similar to the wrought $7075 \mathrm{Al}$ alloy, based on similar activation energies and precipitate particle sizes determined in the current study. As regards precipitate coarsening at the elevated $200^{\circ} \mathrm{C}$ temperature, the GISS

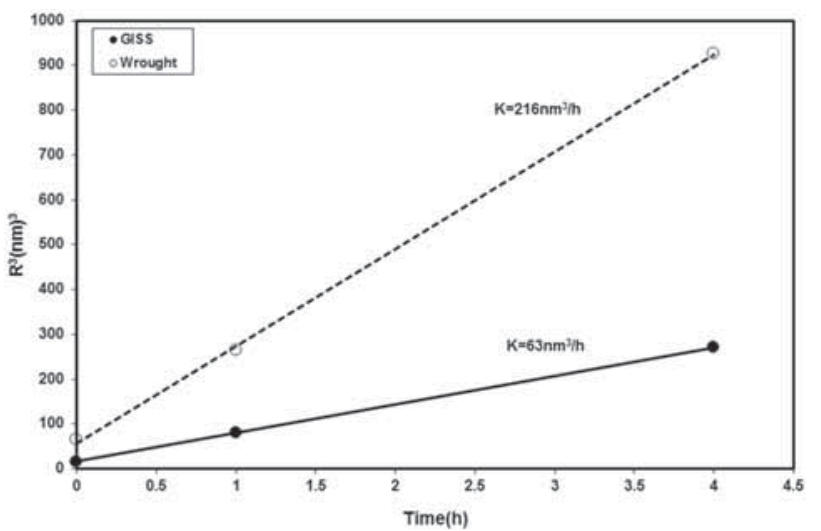

Figure 8. Plot $R^{3} v s$. holding time at $200^{\circ} \mathrm{C}$ for GISS cast 7075-PA (GISS) and wrought $7075 \mathrm{Al}$ alloy (wrought).

7075-PA Al alloy was compared with the wrought 7075T651 Al alloy. $R^{3} v s$. ageing time at $200^{\circ} \mathrm{C}$ is plotted for both alloys in figure 8 . The precipitate coarsening of both alloys at $200^{\circ} \mathrm{C}$ is consistent with the LSW theory as the relationship of $R^{3}$ and ageing time appears linear. However, the $63 \mathrm{~nm}^{3} \mathrm{~h}^{-1}$ coarsening rate of the GISS 7075-PA Al alloy is about three-fold less than that of the wrought 7075-T651 Al alloy $\left(216 \mathrm{~nm}^{3} \mathrm{~h}^{-1}\right)$. The results imply that the precipitates in the microstructure of the wrought alloy are coarser than those in the GISS-T6 PA alloy, at $200^{\circ} \mathrm{C}$, and that the wrought alloy is softened at elevated temperatures [5].

\section{Conclusions}

The SAXS measurements available at the Siam Photon Laboratory, the SLRI, Thailand, were used to estimate the precipitate particle sizes of the GISS cast 7075-T6 Al alloy. The coarsening of precipitates across ageing temperatures in the range from 120 to $185^{\circ} \mathrm{C}$ were well fit by an LSW model for times beyond the peak ageing and the onset of hardness plateau. The $1.19 \mathrm{eV}$ activation energy estimated for the studied alloy suggests that the precipitate coarsening is rate limited by diffusion and close to that of wrought 7075 Al alloys. However, the coarsening rate of fine precipitates in the GISS 7075-PA Al alloy is $63 \mathrm{~nm}^{3} \mathrm{~h}^{-1}$ at a temperature of $200^{\circ} \mathrm{C}$, which is about three-fold less than that of the wrought $7075-\mathrm{T} 651 \mathrm{Al}$ alloy $\left(216 \mathrm{~nm}^{3} \mathrm{~h}^{-1}\right)$. This suggests that the GISS sample could be preferable at elevated temperatures.

\section{Acknowledgements}

This work was financially supported by the Thailand Research Fund (Grant No. MRG5680021) and Prince of Songkla University, Surat Thani Campus (2016). We would like to thank all the staff members of the Siam Photon Laboratory 
(beamline No. 1 : SAXS) of the SLRI for their help in conducting the SAXS experiment, and Associate Prof Dr Seppo Karrila for commenting on the manuscript.

\section{References}

[1] Polmear I J 2006 Light alloy: from traditional alloys to nanocrystals (United Kingdom: Butterworth-Heinemann)

[2] Du Z, Zhou T, Liu P, Li H, Dong B and Chen C 2005 J. Mater. Sci. Technol. 21479

[3] Guyot P and Cottignies C 1996 Acta Mater. 444161

[4] Mahathaninwong N, Plookphol T, Wannasin J and Wisutmethangoon S 2012 Mater. Sci. Eng. A 53291

[5] Mahathaninwong N, Zhou Y, Babcock S E, Plookphol T, Wannasin J and Wisutmethangoon S 2012 Mater. Sci. Eng. A 556 107
[6] Glatter O and Kratky O (eds) 1982 Small angle X-ray scattering (London. Academic Press)

[7] Soontaranon S and Rugmai S 2012 Chin. J. Phys. 50204

[8] Phinjaroenphan S, Soontaranon S, Chirawatkul P, Chaiprapa J, Busayaporn W, Pongampai S et al 2013 J. Phys. Conf. Ser. 4251

[9] SAXSIT Available at: http://www.slri.or.th/th/index.php?option $=$ com_content $\&$ view $=$ article $\& \mathrm{id}=276 \% 3$ Asaxsit-page $\&$ catid $=$ $55 \% 3 \mathrm{Abl13}$ w \& Itemid $=85$

[10] Deschamps A, Livet F and Brechet Y 1999 Acta Mater. 47 281

[11] Liu D, Xiong B, Bian F, Li Z, Li X, Zhang Y et al 2013 Mater. Sci. Eng. A 5881

[12] Zheng L J, Chen C O, Bai P C, Zhou T T, Liu P Y and Dong B Z 2003 Mater. Lett. 5825

[13] Tsao C S, Lin T L and Yu M S 1999 J. Alloys Compd. 28981

[14] Du Z W, Sun Z M, Shao B L, Zhou T T and Chen C Q 2006 Mater. Charact. 56121 